\title{
Impact of Clones in a Clonal Seed Orchard on the Variation of Seed Traits, Germination and Seedling Growth in Santalum album $\mathrm{L}$.
}

\author{
By D. Annapurna, T. S Rathore* and P. V. SomashekHar
}

Tree Improvement and Propagation Division, Institute of Wood Science and Technology, $18^{\text {th }}$ Cross Malleswaram, Bangalore-56003, India

(Received 29 $9^{\text {th }}$ March 2004)

\begin{abstract}
Summary
Clonal Seed Orchard (CSO) of Santalum album L. at Nallal, India consisting of 25 clones originated from different agro-climatic conditions of four southern states (Karnataka, Tamil Nadu, Kerala and Andhra Pradesh) was source of seeds for variability studies. There was vast variation in seed size, weight, germination, vigour and seedling growth of different clones over the years. Seed length, width and weight were positively correlated to each other but seed size had no effect on germination, Germination Value $(\mathrm{GV})$, days taken for germination and early seedling growth. Effects of Clones were dominant and accounted for variation in germination rather than seed size. There was no consistency in the parameters studied in the two years. The impact of these genetic differences in handling of seed lots during bulking, grading and storage for mass propagation of nursery planting stock of $S$. album is also discussed.
\end{abstract}

Key words: CSO, Santalum album, seed variability, clone, correlation and mass propagation.

\section{Introduction}

Santalum album L. commonly known as sandalwood is a hemi-root parasite of the family Santalaceae. It is predominantly out breeding species (ЈYОTHI et al., 1991; BHASKAR, 1992; VEERENDRA and PADMANABHA, 1996), which express variability in the form of leaf size, shape, flowering pattern (period), fruit/seed size, heartwood and oil content (SRINIVASAN et al., 1992; SRIMATHI et al., 1995). Natural variability provides vast scope for genetic improvement and immediate use of superior genotypes/clones seed or clonal planting material for improved productivity in per unit area (particularly heartwood and oil content) in sandalwood.

Forest tree improvement programmes are structured on three main stages; selection, breeding and testing (EL KASSABY et al., 1992). Superior genotypes from the testing stage are propagated to establish orchards for the production of seeds (HAwKINS, 1998). Seeds collected from these orchards are then used for seedling production for reforestation success. However, the goal of the seed orchards is also to maximize diversity.

In the same line, the Sandal Research Center, which later on merged with Institute of Wood Science \& Technology (IWST), Bangalore has selected plus trees of S. album from southern states, based on the growth, heartwood and oil content and established Clonal Germplasm Bank at Gottipura, Bangalore in 1980. Dur-

\footnotetext{
*) Corresponding author: DR. T. S. RATHORE, Fax: 91-080 23340529, E-mail: tsrathore@iwst.res.in
}

ing 1982, Clonal Seed Orchard (CSO) of 25 clones (plus trees of diverse origin from peninsular India) was established using 25 ramets of each clone at Nallal, Bangalore (SRINIVASAN et al., 1992; SRIMATHI et al., 1995). Seeds of the CSO are collected every year and used as a source of quality seed for improved planting stock.

Seed orchards and forest seedling nurseries are interconnected phases of reforestation process (LONG and PEOPLES, 1991). In modern containerized nurseries, uniform germination and seedling growth are considered important to reduce culling percentage and production costs. Seed size fractionation is a common practice used to increase uniformity in seedling size (CAMPBELL and SorEnson, 1984). However, the effect of seed size on germination behaviour is controversial (CHAISURISRI et al., 1992: REICH et al., 1994).

BAGCHI and SHARMA (1989) observed significant genetic variability in seed characters like; seed size and weight from few of the selected plus trees seeds of S. album. VEERENDRA et al. (1999), observed seed size variation (morphological and physiological) in various provenances of $S$. album. Significant correlations of seed characters were observed in S. album (BAGCHI and SHARMA, 1989). In S. album, reports on the effect of seed size on rate of germination and seedling growth are controversial (NAGAVENI and ANATHAPADMANABHA, 1986; VEERENDRA and SARMA, 1990; BRAND et al., 1993; EFFENDI and SinAGA; 1994). Seed source studies of different provenances of $S$. austrocaledonicum exhibited variation in germination after storage of 16-24 month period (CHAUVIN and EHRHART, 1998).

As such there is no information about seed variability in terms of seed size, weight, germination, germination value, early seedling growth and pattern of seed character during different collection years among various clones of CSO of sandal wood, which is essential for handling, management and use for improvement and production of quality planting material for afforestation and conservation point of view.

Based on the gaps in the existing literature, efforts were made to study the seed source variability in terms of seed size, weight, germination percentage, germination value, seedling growth performance among various clones of CSO of sandalwood during different collection years and to find their inter relationship.

\section{Materials and Methods}

Seeds of 25 clones from CSO which was established in 1982 by using scion material of plus trees comprising 
seven clones from Karnataka (K1, K2, K3, K5, K7, K14 and K19), 14 clones from Tamil Nadu (T1, T2, T3, T4, T5, T7, T9, T14, T15, T16, T21, T22, T25 and T26), 3 clones from Kerela (KL1, KL2, KL3) and one clone from Andhra Pradesh (AP4) were used for the present studies.

Ripe fruits with purple orange colour were collected during peak seed setting period in October-November during 1998 and 1999 and depulped by soaking in water for 2 hours followed by rubbing. Seeds were air dried under shade. Processed seeds were stored at $10^{\circ} \mathrm{C}$ temperature in airtight containers in freezer to carry out germination study.

Seed variability: Four replications of 25 randomly selected and undamaged seeds per replication were measured for their length and width in mm upto 2 decimal place using electronic vernier calliper (Mitutoyo, CD-6" CS). Fresh seed weight of randomly selected four

Table 1. - Variability in terms of seed size, weight, germination percentage, time taken for germination and germination value of seed collection in 1998 and 1999 from Clonal Seed Orchard of S. album.

\begin{tabular}{|c|c|c|c|c|c|c|c|c|c|c|c|c|c|}
\hline \multirow[t]{2}{*}{$\begin{array}{l}\text { Sl. } \\
\text { No. }\end{array}$} & \multirow[t]{2}{*}{ Clone } & \multicolumn{2}{|c|}{$\begin{array}{l}\text { Seed length } \\
(\mathrm{mm})\end{array}$} & \multicolumn{2}{|c|}{$\begin{array}{l}\text { Seed width } \\
(\mathrm{mm})\end{array}$} & \multicolumn{2}{|c|}{$\begin{array}{c}100 \text { seed weight } \\
\text { (g) }\end{array}$} & \multicolumn{2}{|c|}{$\begin{array}{c}\text { Germination } \\
(\%)\end{array}$} & \multicolumn{2}{|c|}{$\begin{array}{c}\text { Time taken } \\
\text { for } \\
\text { germination } \\
\text { (days) }\end{array}$} & \multicolumn{2}{|c|}{$\begin{array}{c}\text { Germination } \\
\text { value } \\
\text { (GV) }\end{array}$} \\
\hline & & 1998 & 1999 & 1998 & 1999 & 1998 & 1999 & 1998 & 1999 & 1998 & 1999 & 1998 & 1999 \\
\hline 1 & K1 & 7.28 & 7.26 & 6.77 & 6.70 & 15.34 & 14.41 & $10.67(18.85)$ & $10.67(18.73)$ & 46.3 & 39.67 & 0.051 & 0.052 \\
\hline 2 & K2 & 7.75 & 6.91 & 6.98 & 6.54 & 15.95 & 14.21 & $45.33(42.27)$ & $50.67(45.38)$ & 50.3 & 41.00 & 0.807 & 1.147 \\
\hline 3 & K3 & 7.37 & 7.31 & 6.90 & 6.58 & 15.07 & 14.74 & $27.67(31.63)$ & $21.33(27.38)$ & 54.3 & 47.67 & 0.283 & 0.170 \\
\hline 4 & K5 & 7.32 & 7.29 & 6.72 & 6.62 & 15.84 & 13.81 & $26.33(30.75)$ & $3.33(10.40)$ & 50.3 & 45.00 & 0.265 & 0.005 \\
\hline 5 & K7 & 7.64 & 7.71 & 6.82 & 6.78 & 16.20 & 15.61 & $35.67(36.63)$ & $30.67(33.54)$ & 49.7 & 48.33 & 0.513 & 0.356 \\
\hline 6 & K14 & 6.78 & 7.94 & 6.02 & 6.89 & 16.14 & 16.63 & $80.33(63.70)$ & $40.67(39.46)$ & 47.7 & 43.00 & 2.625 & 0.794 \\
\hline 7 & K19 & 7.60 & 7.57 & 6.59 & 6.55 & 13.80 & 14.79 & $42.33(40.51)$ & $20.67(27.00)$ & 46.3 & 49.00 & 0.784 & 0.164 \\
\hline 8 & T1 & 7.49 & 7.36 & 6.94 & 6.67 & 16.55 & 14.16 & $31.00(33.67)$ & $18.67(25.55)$ & 48.3 & 47.00 & 0.393 & 0.118 \\
\hline 9 & $\mathrm{~T} 2$ & 7.08 & 7.88 & 6.52 & 7.09 & 15.82 & 18.6 & $30.33(33.41)$ & $26.67(30.88)$ & 52.3 & 41.67 & 0.334 & 0.313 \\
\hline 10 & T3 & 7.66 & 7.17 & 7.02 & 6.51 & 17.12 & 14.33 & $34.67(35.99)$ & $36.00(36.75)$ & 50.3 & 43.67 & 0.489 & 0.568 \\
\hline 11 & T4 & 7.42 & 7.28 & 6.82 & 6.50 & 15.02 & 14.46 & $14.67(22.16)$ & $6.00(14.05)$ & 53.7 & 43.00 & 0.081 & 0.016 \\
\hline 12 & T5 & 7.65 & 7.58 & 6.82 & 6.74 & 15.03 & 14.61 & $61.00(49.41)$ & $04.67(12.42)$ & 49.7 & 33.00 & 1.428 & 0.012 \\
\hline 13 & $\mathrm{~T} 7$ & 7.87 & 7.39 & 7.12 & 6.73 & 15.66 & 14.77 & $11.67(19.83)$ & $11.33(19.66)$ & 53.0 & 43.00 & 0.050 & 0.540 \\
\hline 14 & T9 & 7.53 & 8.19 & 7.07 & 7.42 & 17.64 & 19.07 & $36.67(37.21)$ & $04.00(11.28)$ & 52.3 & 40.33 & 0.494 & 0.009 \\
\hline
\end{tabular}

Table 1. - Continued.

\begin{tabular}{|c|c|c|c|c|c|c|c|c|c|c|c|c|c|}
\hline \multirow[t]{2}{*}{$\begin{array}{l}\text { SI. } \\
\text { No. }\end{array}$} & \multirow[t]{2}{*}{ Clone } & \multicolumn{2}{|c|}{$\begin{array}{l}\text { Seed length } \\
(\mathrm{mm})\end{array}$} & \multicolumn{2}{|c|}{$\begin{array}{l}\text { Seed width } \\
\quad(\mathrm{mm})\end{array}$} & \multicolumn{2}{|c|}{$\begin{array}{c}100 \text { seed } \\
\text { weight }(g)\end{array}$} & \multicolumn{2}{|c|}{$\begin{array}{c}\text { Germination } \\
(\%)\end{array}$} & \multicolumn{2}{|c|}{$\begin{array}{l}\text { Time taken for } \\
\text { germination } \\
\text { (days) }\end{array}$} & \multicolumn{2}{|c|}{$\begin{array}{c}\text { Germination } \\
\text { value } \\
(\text { GV) }\end{array}$} \\
\hline & & 1998 & 1999 & 1998 & 1999 & 19989 & 1999 & 1998 & 1999 & 1998 & 1999 & 1998 & 1999 \\
\hline 15 & T14 & 7.91 & 7.35 & 7.04 & 6.76 & 17.37 & 15.01 & $48.33(44.03)$ & $11.67(19.88)$ & 50.3 & 38.33 & 0.924 & 0.069 \\
\hline 16 & T15 & 7.61 & 7.34 & 6.85 & 6.64 & 16.19 & 13.82 & $15.33(22.70)$ & $25.33(30.19)$ & 53.0 & 44.33 & 0.090 & 0.267 \\
\hline 17 & T16 & 7.75 & 8.25 & 6.81 & 7.28 & 16.53 & 19.87 & $53.67(47.12)$ & $8.00(16.35)$ & 50.3 & 42.33 & 1.163 & 0.026 \\
\hline 18 & $\mathrm{~T} 21$ & 7.26 & 7.20 & 6.81 & 6.77 & 17.09 & 15.89 & $26.33(30.88)$ & \begin{tabular}{|l|l|}
$00.00(0.00)$ \\
\end{tabular} & 42.3 & - & 0.332 & 0.000 \\
\hline 19 & $\mathrm{~T} 22$ & 7.89 & 7.10 & 7.03 & 6.30 & 18.79 & 12.65 & $35.33(36.43)$ & 08.0 & 52.3 & 44.33 & 0.505 & 0.027 \\
\hline 20 & T25 & 7.51 & 7.17 & 6.94 & 6.68 & 16.59 & 14.99 & $15.00(22.22)$ & $00.00(0.00)$ & 54.3 & - & 0.092 & 0.000 \\
\hline 21 & T26 & 7.73 & 7.34 & 6.98 & 6.76 & 16.34 & 14.74 & $32.33(34.41)$ & $04.00(11.54)$ & 50.3 & 38.33 & 0.445 & 0.007 \\
\hline 22 & KL1 & 7.28 & 8.03 & 6.76 & 7.05 & 14.78 & 18.16 & $11.67(19.79)$ & $28.33(31.95)$ & 54.3 & 49.00 & 0.052 & 0.325 \\
\hline 23 & KL2 & 7.70 & 8.32 & 7.04 & 7.45 & 18.61 & 21.09 & $45.33(42.31)$ & $18.67(25.40)$ & 51.7 & 43.00 & 0.845 & 0.173 \\
\hline 24 & KL3 & 8.42 & 7.50 & 7.61 & 6.70 & 21.57 & 14.81 & $19.00(25.69)$ & $10.00(17.87)$ & 52.3 & 40.33 & 0.140 & 0.053 \\
\hline 25 & AP4 & 7.64 & 7.35 & 7.09 & 6.72 & 16.50 & 14.21 & $39.33(38.82)$ & $18.00(25.07)$ & 53.7 & 47.00 & 0.559 & 0.127 \\
\hline \multicolumn{14}{|c|}{ LSD } \\
\hline \multirow{2}{*}{\multicolumn{2}{|c|}{$\begin{array}{c}\mathrm{C} \\
\mathrm{CX} Y\end{array}$}} & \multicolumn{2}{|c|}{0.180} & \multicolumn{2}{|c|}{0.082} & \multicolumn{2}{|c|}{0.458} & \multicolumn{2}{|c|}{6.020} & \multicolumn{2}{|c|}{10.92} & \multicolumn{2}{|c|}{0.55} \\
\hline & & \multicolumn{2}{|c|}{0.024} & \multicolumn{2}{|c|}{0.016} & \multicolumn{2}{|c|}{0.092} & \multicolumn{2}{|c|}{1.21} & \multicolumn{2}{|c|}{2.19} & \multicolumn{2}{|c|}{0.11} \\
\hline
\end{tabular}

$\mathrm{LSD}^{*}=$ Least significant difference at $\alpha=0.05$ 
samples of each seed source, consisting of 100 seeds was recorded as per ISTA (1993) rules using electronic top pan balance (Adair Dutt MJ-300).

The seeds collected from 25 clones ramets were pretreated with $\mathrm{GA}_{3}, 500 \mathrm{ppm}(\mathrm{w} / \mathrm{v})$ for 16 hours and germinated at $30 \pm 1{ }^{\circ} \mathrm{C}$ temperature and $95 \%$ relative humidity in plastic trays ( sand as a germination medium in seed germinator. Three replications of 50 seeds per replication from each seed source were used in a completely randomized design. Sprays of fungicides, Dithane M-45, 0.25\% (w/w) and Bavistin, $0.1 \%(\mathrm{w} / \mathrm{w})$ was given alternatively at weekly interval as a prophylactic measures. Seed was considered germinated, when the plumule had emerged about $1 \mathrm{~cm}$. Germination count was recorded on alternate days, up to 60 days. Total germination percentage, number of days to complete germination and Germination Value an index combining speed and completeness of seed germination was calculated (CZABATOR, 1962).

Seedling variability: The seedlings of 24 clones (except, K1) were transferred to 270 cc block type root trainers during 1999, for 1998 seed collection. For seeds collected in 1999, sowing was done during January, 2000. Three replications consisting 12 seedlings per replication were used to record seedling height $(\mathrm{cm})$ and collar diameter $(\mathrm{mm})$ at 6 months age in the first year and at 3 months age for selected 6 clones (K19, T4, T16, T22, KL1 and KL3) in the second year (2000).

Statastical analysis: Data on seed length, seed width, 100 seed weight, germination percentage, germination value and days taken for germination for two years were analysed using factorial ANOVA. Between both the years, variability of clones in terms of seed traits and germination parameters were analysed according to Wilcoxon Matched Pairs Signed Rank test (PHANSE and SuKHATME, 1978). Seedling height and collar diameter were analysed using one way ANOVA (PHANsE and SuKHATME, 1978). Correlation coefficients of seed characters, germination parameters and seedling growth were assessed using MS Excel version 5.0.

\section{Results}

\section{Studies on Seed Variability of 1998 Seed Collection}

Data on seed length, seed width, 100 seed weight, germination percentage, days taken for germination, germination value of seed from 25 different clones in both the years revealed significant differences between clones and years (Table 1).

In the year 1998, the mean seed length varied from $6.78 \mathrm{~mm}$ (K14) to $8.42 \mathrm{~mm}$ (KL3). The highest value for seed width was recorded in KL3 $(7.61 \mathrm{~mm})$, followed by T7 (7.12 mm) and AP4 (7.09 mm). Minimum seed width was found in K14 $(6.02 \mathrm{~mm})$. Seed weight varied from $13.80 \mathrm{~g}$ to $21.57 \mathrm{~g}$ and maximum in KL3. KL3, which has maximum seed length and width, also had maximum seed weight. Minimum seed weight was recorded in K19 (13.80 g).

In the second year, seed length varied from $6.91 \mathrm{~mm}$ to $8.32 \mathrm{~mm}$. Highest seed length was recorded in KL2 (8.32 $\mathrm{mm})$. K2 recorded minimum seed length (6.91 $\mathrm{mm}$ ), which was significantly lower than seeds of all the other clones. The clone KL2, in which seed length was maximum, expressed highest value $(7.45 \mathrm{~mm})$ for seed width. Lowest value for seed width $(6.30 \mathrm{~mm})$ was recorded in clone T22 that was significantly different from all other clones. Data on 100 seed weight varied from $12.65 \mathrm{~g}$ to $21.09 \mathrm{~g}$. The clone KL2, in which highest value for seed length and seed width was observed, expressed highest value for 100 seed weight (21.09 g), which was significantly higher than all other clones. This was followed by T16 (19.87 g) and T9 (19.07 g). Lowest value for 100 seed weight was recorded in clone T22 (12.65 g).

During 1998, maximum variability was observed in percentage seed germination, which varied from $10.67 \%$ to $80.33 \%$. Highest germination was recorded in K14 $(80.33 \%)$, which had minimum seed width. This was followed by T16 (53.67\%), which was at par with T14 $(48.33 \%)$ and $\mathrm{K} 2(45.33 \%)$. Lowest germination was observed in $\mathrm{K} 1(10.67 \%)$. Time taken for germination (in days) varied from 42.3 to 54.3 and it was minimum in $\mathrm{T} 21$, which was on par with K1 and K19 (46.3), whereas, $\mathrm{KL} 1, \mathrm{~T} 25$ and $\mathrm{K} 3$ took maximum number of days for germination. Germination value $(\mathrm{GV})$, varied significantly among seeds of different clones and highest GV was observed in K14 (2.625), which was significantly superior $(p=0.05)$ to all other clones, and the same clone seed exhibited maximum germination percentage, too. GV was minimum in T7 (0.050).

In the second year, seed germination was poor as compared to seeds of the first year i.e. 1998. Germination percentage of second year seed varied from $4.0 \%$ to $50.67 \%$ and no germination was observed from the seeds of the clone T21 and T26. The clone K2, which expressed minimum value for seed length, exhibited maximum germination $(50.67 \%)$, which was significantly, higher than all other clones. This was followed by K14 $(40.67 \%)$ and T3 $(36.00 \%)$. The clone KL2 that expressed maximum value for seed length, seed width and 100 seed weight had comparative low germination percentage of 18.67. Minimum germination period was taken by T5 (33 days) and maximum by K19 and KL1 (49 days). Germination value was highest in K2 (1.147), which also expressed maximum germination percentage.

As such, there was no trend or relationship between seed characters and germination percentage and germination value among different clones for both the years. Data subjected to Wilcoxin matched pairs Signed ranks test also revealed significant differences between clones in different years. The ranks differed significantly between the years for all the characters like; seed length, seed width, 100 seed weight, germination, germination value and days taken for germination (Table 2) In majority of clones, the germination percentage was high in 1998 seed collection as compared to 1999.

Growth performance of seedlings raised from seeds of various clones exhibited significant variation in terms of height and collar diameter for both the years (Table 3 and Table 4). In the first year, seedling height varied from $17.99 \mathrm{~cm}$ to $28.21 \mathrm{~cm}$ and it was maximum in $\mathrm{K} 19$, 
Table 2. - Ranks of seed size, weight, germination percentage, time taken for germination and germination value of seed collection in 1998 and 1999 from Clonal Seed Orchard of S. album.

\begin{tabular}{|c|c|c|c|c|c|c|c|c|c|c|c|c|c|}
\hline \multirow[t]{2}{*}{ SI. No. } & \multirow[t]{2}{*}{ Clone } & \multicolumn{2}{|c|}{$\begin{array}{l}\text { Seed length } \\
(\mathrm{mm})\end{array}$} & \multicolumn{2}{|c|}{$\begin{array}{l}\text { Seed width } \\
(\mathrm{mm})\end{array}$} & \multicolumn{2}{|c|}{$\begin{array}{c}100 \text { seed weight } \\
\text { (g) }\end{array}$} & \multicolumn{2}{|c|}{$\begin{array}{c}\text { Germination } \\
(\%)\end{array}$} & \multicolumn{2}{|c|}{$\begin{array}{c}\text { Time taken for } \\
\text { germination (days) }\end{array}$} & \multicolumn{2}{|c|}{$\begin{array}{c}\text { Germination } \\
\text { value } \\
(\mathbf{G V})\end{array}$} \\
\hline & & 1998 & 1999 & 1998 & 1999 & 1998 & 1999 & 1998 & 1999 & 1998 & 1999 & 1998 & 1999 \\
\hline 1 & K1 & 22 & 20 & 20 & 14 & 20 & 18 & 25 & 15 & 2 & 4 & 24 & 15 \\
\hline 2 & K2 & 6 & 25 & 9 & 22 & 16 & 20 & 5 & 1 & 8 & 7 & 6 & 1 \\
\hline 3 & K3 & 19 & 17 & 13 & 20 & 21 & 14 & 16 & 8 & 23 & 20 & 17 & 9 \\
\hline 4 & K5 & 20 & 18 & 22 & 19 & 17 & 24 & 17 & 23 & 9 & 17 & 18 & 23 \\
\hline 5 & K7 & 12 & 7 & 15 & 7 & 13 & 8 & 10 & 4 & 6 & 21 & 9 & 4 \\
\hline 6 & K14 & 25 & 5 & 25 & 6 & 15 & 6 & 1 & 2 & 4 & 10 & 1 & 2 \\
\hline 7 & K19 & 14 & 9 & 23 & 21 & 25 & 12 & 7 & 9 & 3 & 22 & 7 & 10 \\
\hline 8 & $\mathrm{~T} 1$ & 17 & 12 & 11 & 17 & 9 & 22 & 14 & 10 & 5 & 18 & 14 & 12 \\
\hline 9 & $\mathrm{~T} 2$ & 24 & 6 & 24 & 4 & 18 & 4 & 15 & 6 & 15 & 8 & 15 & 6 \\
\hline 10 & T3 & 9 & 22 & 8 & 23 & 6 & 19 & 12 & 3 & 10 & 14 & 12 & 3 \\
\hline 11 & T4 & 18 & 19 & 16 & 24 & 23 & 17 & 22 & 19 & 21 & 11 & 22 & 19 \\
\hline 12 & T5 & 10 & 8 & 17 & 11 & 22 & 16 & 2 & 20 & 7 & 1 & 2 & 20 \\
\hline 13 & $\mathrm{~T} 7$ & 4 & 11 & 2 & 12 & 19 & 13 & 23 & 14 & 19 & 12 & 25 & 14 \\
\hline 14 & T9 & 15 & 3 & 4 & 2 & 4 & 3 & 9 & 21 & 16 & 5 & 11 & 21 \\
\hline
\end{tabular}

Contd.

Table 2. - Continued.

\begin{tabular}{|c|c|c|c|c|c|c|c|c|c|c|c|c|c|}
\hline \multirow[t]{2}{*}{ SI. No. } & \multirow[t]{2}{*}{ Clone } & \multicolumn{2}{|c|}{$\begin{array}{l}\text { Seed length } \\
(\mathrm{mm})\end{array}$} & \multicolumn{2}{|c|}{$\begin{array}{l}\text { Seed width } \\
(\mathrm{mm})\end{array}$} & \multicolumn{2}{|c|}{$\begin{array}{c}100 \text { seed weight } \\
\text { (g) }\end{array}$} & \multicolumn{2}{|c|}{$\begin{array}{c}\text { Germination } \\
(\%)\end{array}$} & \multicolumn{2}{|c|}{$\begin{array}{l}\text { Time taken for } \\
\text { germination } \\
\text { (days) }\end{array}$} & \multicolumn{2}{|c|}{$\begin{array}{c}\text { Germination } \\
\text { value } \\
\text { (GV) }\end{array}$} \\
\hline & & 1998 & 1999 & 1998 & 1999 & 1998 & 1999 & 1998 & 1999 & 1998 & 1999 & 1998 & 1999 \\
\hline 15 & T14 & 2 & 13 & 6 & 9 & 5 & 9 & 4 & 13 & 11 & 2 & 4 & 13 \\
\hline 16 & T15 & 13 & 15 & 14 & 18 & 14 & 23 & 20 & 7 & 20 & 15 & 21 & 7 \\
\hline 17 & T16 & 5 & 2 & 19 & 3 & 10 & 2 & 3 & 17 & 12 & 9 & 3 & 18 \\
\hline 18 & T21 & 23 & 21 & 18 & 8 & 7 & 7 & 18 & 24 & 1 & 24 & 16 & 24 \\
\hline 19 & T22 & 3 & 24 & 7 & 25 & 2 & 25 & 11 & 18 & 17 & 16 & 10 & 17 \\
\hline 20 & $\mathrm{~T} 25$ & 16 & 23 & 12 & 16 & 8 & 10 & 21 & 25 & 24 & 25 & 20 & 25 \\
\hline 21 & T26 & 7 & 16 & 10 & 10 & 12 & 15 & 13 & 22 & 13 & 3 & 13 & 22 \\
\hline 22 & KL1 & 21 & 4 & 21 & 5 & 24 & 5 & 24 & 5 & 25 & 23 & 23 & 5 \\
\hline 23 & KL2 & 8 & 1 & 5 & 1 & 3 & 1 & 6 & 11 & 14 & 13 & 5 & 8 \\
\hline 24 & KL3 & 1 & 10 & 1 & 15 & 1 & 11 & 19 & 16 & 18 & 6 & 19 & 16 \\
\hline 25 & AP4 & 11 & 14 & 3 & 13 & 11 & 21 & 8 & 12 & 22 & 19 & 8 & 11 \\
\hline T observed & -- & \multicolumn{2}{|c|}{163} & \multicolumn{2}{|c|}{154} & \multicolumn{2}{|c|}{148} & \multicolumn{2}{|c|}{163} & \multicolumn{2}{|c|}{128} & \multicolumn{2}{|c|}{163.5} \\
\hline
\end{tabular}

$\mathrm{T}$ critical value at $\alpha 0.05=90$

which was on par with $\mathrm{K} 3(27.40 \mathrm{~cm})$, T2 $(26.25 \mathrm{~cm})$ and KL3 $(25.92 \mathrm{~cm})$. Among these, clone K19 exhibited minimum seed weight, whereas, KL3 expressed maximum seed weight (Table 1). Seedling height was minimum in T16 which was on par with K7, KL1, T7, AP4, T9 and T14. Collar diameter varied from $2.21 \mathrm{~mm}$ to $3.77 \mathrm{~mm}$ and it was found maximum in KL2 and minimum in T7.

Initial seedling growth at the age of 3 months was measured for 6 selected clones (Table 4). Seedlings of various clones exhibited variation in terms of height and collar diameter. Seedling height varied from $11.76 \mathrm{~cm}$ to $14.38 \mathrm{~cm}$ and collar diameter from $2.18 \mathrm{~mm}$ to $2.93 \mathrm{~mm}$.
Seedling height and collar diameter were maximum in T4 (14.93 $\mathrm{cm}$ and $2.93 \mathrm{~mm}$, respectively) and minimum in T22 (11.76 $\mathrm{cm}$ and $2.18 \mathrm{~mm}$, respectively). Though seed length, width and 100 seed weight were maximum in T16, but seedling height and collar diameter were less than $\mathrm{T} 4$.

In both the years $(1998,1999)$, seed length was positively correlated to seed width $(0.867,0.979)$ and 100 seed weight $(0.571,0.983)$ and seed width was correlated to 100 seed weight $(0.623,0.988)$. Of 1998 seed collection, seed width was negatively correlated to germination percentage $(-0.459)$. In both the years, germination 
Table 3. - Seedling growth performance of $S$. album in terms of height and collar diameter at the age of 6 months in 24 clones seedlings of 1998 seed collection.

\begin{tabular}{|c|c|c|c|}
\hline SI. No. & Clone & Seedling height (cm) & Collar diameter (mm) \\
\hline 1 & K2 & 25.19 & 3.26 \\
\hline 2 & K3 & 27.40 & 3.45 \\
\hline 3 & K5 & 23.79 & 3.10 \\
\hline 4 & K7 & 19.46 & 2.45 \\
\hline 5 & K14 & 25.15 & 3.14 \\
\hline 6 & K19 & $\mathbf{2 8 . 2 1}$ & 3.31 \\
\hline 7 & T1 & 22.30 & 2.93 \\
\hline 8 & T2 & 26.25 & 3.61 \\
\hline 9 & T3 & 22.62 & 2.87 \\
\hline 10 & T4 & 23.6 & 3.02 \\
\hline 11 & T5 & 22.76 & 2.68 \\
\hline 12 & T7 & 20.30 & $\mathbf{2 . 2 1}$ \\
\hline 13 & T9 & 20.96 & 2.54 \\
\hline 14 & T14 & 21.24 & 3.08 \\
\hline 15 & T15 & 21.89 & 2.67 \\
\hline 16 & T16 & $\mathbf{1 7 . 9 9}$ & 2.49 \\
\hline 17 & T21 & 24.54 & 3.12 \\
\hline 18 & T22 & 23.46 & 3.35 \\
\hline 19 & T25 & 23.88 & 2.90 \\
\hline 20 & T26 & 23.65 & 3.21 \\
\hline 21 & KL1 & 20.24 & 2.42 \\
\hline 22 & KL2 & 25.04 & $\mathbf{3 . 7 7}$ \\
\hline 23 & KL3 & 25.92 & 3.00 \\
\hline 24 & AP4 & 20.85 & 2.45 \\
\hline SE & -- & $\mathbf{1 . 9 5}$ & $\mathbf{0 . 3 0}$ \\
\hline LSD & -- & $\mathbf{3 . 8 2}$ & $\mathbf{0 . 5 9}$ \\
\hline & & & \\
\hline
\end{tabular}

Table 4. - Seedling growth performance of $S$. album in terms of height and collar diameter at the age of 3 months in 6 selected clones seedlings of 1999 seed collection.

\begin{tabular}{|c|c|c|c|}
\hline Sl. No & Clone & Seedling height (cm) & Collar diameter (mm) \\
\hline 1 & T16 & 14.38 & 2.78 \\
\hline 2 & K19 & 13.8 & 2.61 \\
\hline 3 & T4 & $\mathbf{1 4 . 9 3}$ & $\mathbf{2 . 9 3}$ \\
\hline 4 & KL1 & 13.69 & 2.57 \\
\hline 5 & KL3 & 14.75 & 2.74 \\
\hline 6 & T22 & $\mathbf{1 1 . 7 6}$ & $\mathbf{2 . 1 8}$ \\
\hline SE & -- & $\mathbf{0 0 . 6 8}$ & $\mathbf{0 . 1 3}$ \\
\hline LSD $^{*}$ & -- & $\mathbf{0 1 . 4 3}$ & $\mathbf{0 . 2 7}$ \\
\hline
\end{tabular}

$*$ LSD $=$ Least Significant Difference at $\alpha=0.05$

percentage and germination value were positively correlated. Seedling height also expressed positive correlation with collar diameter.

Details of correlation coefficients for different parameters like; seed length, seed width, 100 seed weight, germination percentage, days taken for germination, germination value and initial seedling growth are presented in table 5 for 1998 seed collection and in table 6 for 1999 seed collection.

\section{Discussion}

Seed weight, depends on reserve food material, which is produced as a result of double fertilisation (endosperm) and is dominated by the maternal traits and is also influenced by the nutrient availability at the time of seed setting and environmental factors (ALLEN, 1960; Johnsen et al., 1989). Embryo development and its physiological function are contributed by the maternal as well as by paternal (pollen grain) traits in the species.
In the present study, the seeds of various clones of CSO exhibited significant variability in seed size, seed weight, germination percentage, germination value, time taken for germination and initial seedling growth. Significant variability of seed characters like; seed size and weight was observed in seeds of the selected plus trees (BAGCHI and SHARMA, 1989) and among various provenances of $S$. album (VEERENDRA et al., 1999). This type of variability in seed morphology and germination is attributed to the out breeding nature of sandalwood. Among 19 trees of seed orchard of Pseudotsuga menziesii, variation was observed for germination capacity (26-96\%), peak value, days taken for germination and mean daily germination (EL-KASSABY et al., 1992). Similarly, CHAISURISRI et al. (1992), found wide differences in germination capacity in seeds of 18 clones of Picea sitchiensis.

In the present study, seed characters; seed length, width and weight were significantly and positively correlated to each other. Similarly, positive correlation of seed characters were observed in seed of $S$. album 
(BAGCHI and SHARMA, 1989), Leucaena leucocephala (HoODA and BAHADUR, 1993) and Prosopis cineraria (BAHADUR and HoODA, 1995). As such, there was no trend or relationship between seed characters and germination percentage, germination value and initial seedling growth among different clones, where as earlier reports of NAGAVENI and ANANTHAPADMANABHA (1986) and BRAND et al. (1993) on the effect of seed size on rate of germination and seedling growth are contradictory.

In the present study, it was revealed that genotype or clone had a greater influence on germination and seed size had no relationship with germination percentage, germination value and initial seedling growth, over the years. Similar to our findings, EL-KASSABY et al. (1992) observed no relationship in seed size (weight) on germination capacity and speed in Pseudotsuga menziesii seeds of 19 seed orchard trees. INDIRA et al. (2000), found that fruit size $(9-18 \mathrm{~mm}$, except very small, 6-9 $\mathrm{mm}$ ) did not have influence on seed germination, seedling survival and seedling growth in Tectona grandis.

The seed characters expressed in terms of germination and initial seedling growth differed over the years during the study period. The results revealed that in most of the cases, germination was high in the first year (1998, seed lot), which ranged from $19.33 \%$ to $80.33 \%$ and comparatively low $(4.0 \%$ to $50.67 \%)$ in the second year (1999, seed lots). This might be attributed to the difference in the environmental conditions particularly rainfall and temperature (Appendix 1) during flowering period (May-June). During 1998, the mean temperature was high $\left(33^{\circ} \mathrm{C}\right)$ as compared to 1999 (around $30^{\circ} \mathrm{C}$ ) and rainfall was less $(41.7 \mathrm{~mm}$ and $7.4 \mathrm{~mm})$ as compared to 1999 (143.3 $\mathrm{mm}$ and $43.9 \mathrm{~mm}$ ), which might have affected seed setting and quality of seed. Environmental pre-conditioning during seed development is considered crucial factor in influencing seed

Table 5. - Correlation coefficients of seed size, weight, germination percentage, time taken for germination, germination value and seedling growth of 1998 seed collection from Clonal Seed Orchard of S. album.

\begin{tabular}{|c|c|c|c|c|c|c|c|c|}
\hline Parameter & $\begin{array}{l}\text { Seed } \\
\text { length } \\
(\mathrm{mm})\end{array}$ & $\begin{array}{l}\text { Seed width } \\
(\mathrm{mm})\end{array}$ & $\begin{array}{c}100 \text { seed } \\
\text { weight }(\mathrm{g})\end{array}$ & $\begin{array}{c}\text { Germination } \\
(\%)\end{array}$ & $\begin{array}{c}\text { Time taken for } \\
\text { germination } \\
\text { (days) }\end{array}$ & $\begin{array}{c}\text { Germination } \\
\text { value } \\
\text { (GV) } \\
\end{array}$ & $\begin{array}{c}\text { Seedling } \\
\text { height } \\
\text { (cm) }\end{array}$ & $\begin{array}{c}\text { Collar } \\
\text { diameter } \\
(\mathrm{mm})\end{array}$ \\
\hline $\begin{array}{l}\text { Seed length } \\
(\mathrm{mm})\end{array}$ & -- & & & & & & & \\
\hline $\begin{array}{l}\text { Seed width } \\
(\mathrm{mm})\end{array}$ & $0.867^{*}$ & -- & & & & & & \\
\hline $\begin{array}{l}100 \text { seed weight } \\
\text { (g) }\end{array}$ & $0.571^{*}$ & $0.623^{*}$ & -- & & & & & \\
\hline $\begin{array}{l}\text { Germination } \\
(\%)\end{array}$ & -0.193 & $-0.459^{*}$ & -0.027 & -- & & & & \\
\hline $\begin{array}{l}\text { Time taken for } \\
\text { germination } \\
\text { (days) }\end{array}$ & 0.208 & 0.348 & 0.060 & -0.437 & -- & & & \\
\hline $\begin{array}{l}\text { Germination } \\
\text { Value (GV) }\end{array}$ & -0.297 & $-0.571^{*}$ & -0.071 & $0.957 *$ & -0.415 & -- & & \\
\hline $\begin{array}{l}\text { Seedling height } \\
\text { (cm) }\end{array}$ & -0.183 & -0.170 & -0.005 & 0.054 & -0.189 & 0.060 & -- & \\
\hline $\begin{array}{l}\text { Collar diameter } \\
(\mathrm{mm})\end{array}$ & -0.167 & -0.174 & 0.145 & 0.195 & -0.186 & 0.133 & $0.817^{*}$ & -- \\
\hline
\end{tabular}

* Significant at $\alpha=0.05$

Table 6. - Correlation coefficients of seed size, weight, germination percentage, time taken for germination, germination value and seedling growth of 1999 seed collection from Clonal Seed Orchard of S. album.

\begin{tabular}{|c|c|c|c|c|c|c|c|c|}
\hline Parameter & $\begin{array}{c}\text { Seed } \\
\text { length } \\
(\mathrm{mm})\end{array}$ & $\begin{array}{l}\text { Seed width } \\
\text { (mm) }\end{array}$ & $\begin{array}{c}100 \text { seed } \\
\text { weight }(g)\end{array}$ & $\begin{array}{c}\text { Germination } \\
(\%)\end{array}$ & $\begin{array}{c}\text { Time taken for } \\
\text { germination } \\
\text { (days) }\end{array}$ & $\begin{array}{c}\text { Germination } \\
\text { value } \\
\text { (GV) } \\
\end{array}$ & $\begin{array}{c}\text { Seedling } \\
\text { height } \\
\text { (cm) }\end{array}$ & $\begin{array}{c}\text { Collar } \\
\text { diameter } \\
(\mathrm{mm})\end{array}$ \\
\hline $\begin{array}{l}\text { Seed length } \\
(\mathrm{mm})\end{array}$ & -- & & & & & & & \\
\hline $\begin{array}{l}\text { Seed width } \\
(\mathrm{mm})\end{array}$ & $0.979 *$ & -- & & & & & & \\
\hline $\begin{array}{l}100 \text { seed weight } \\
\text { (g) }\end{array}$ & $0.983^{*}$ & $0.988^{*}$ & -- & & & & & \\
\hline $\begin{array}{l}\text { Germination } \\
(\%)\end{array}$ & 0.410 & 0.281 & 0.302 & -- & & & & \\
\hline $\begin{array}{l}\text { Time taken for } \\
\text { germination } \\
\text { (days) }\end{array}$ & 0.149 & 0.065 & 0.041 & 0.347 & -- & & & \\
\hline $\begin{array}{l}\text { Germination } \\
\text { Value (GV) }\end{array}$ & 0.371 & 0.303 & 0.266 & $0.908^{*}$ & 0.419 & -- & & \\
\hline $\begin{array}{l}\text { Seedling height } \\
\text { (cm) }\end{array}$ & 0.348 & 0.412 & 0.394 & -0.105 & 0.580 & 0.063 & -- & \\
\hline $\begin{array}{l}\text { Collar diameter } \\
(\mathrm{mm})\end{array}$ & 0.335 & 0.398 & 0.404 & -0.075 & 0.477 & -0.069 & $0.979 *$ & -- \\
\hline
\end{tabular}

* Significant at $\alpha=0.05$ 
behavior (JOHNSEN et al., 1989). Seeds from reciprocal crosses of different ramets of same clone and during different years from the same tree can have considerable variation in their ability to germinate and grow (PERRY and HAFLEY, 1981).

In the present study, the interaction effect of clones and years was significant. In other words, the clones expressed differences in the seed traits, germination, germination value and days taken for germination during different years. This might be due to the difference in the genetic make up of various clones and environmental factors during seed pre-conditioning i.e. genotype and environmental interaction.

From this study, it was found that genotype/clone had greater influence on germination and seed size had no relationship with germination and seedling growth in nursery. The seed characters and germination varied during 2 years indicating genotype environmental interaction. These findings have following implications while handling of seedlots during bulking, grading and storage:

1.) Seed size or weight cannot be used as a criteria for grading of bulked seed lots of different clones, as it can narrow down genetic diversity by rejecting small size of seeds. Similarly, HaWkins (1998) opinioned that seed size and its correlation to germination and using them as grading criteria can narrow down seed source genetic diversity.

2.) In case of $S$. album, seeds should be stored with identity of individual clone or family to ensure sustained availability of seeds during poor seed setting period (years).

3.) Grading of individual clone/family seed may be helpful in elimination of extremes of seed (too small and too large) sizes to obtain comparatively uniform seedlings. Bulking without knowing individual tree/clone seed behaviour can be disadvantageous in growing trees.

Appendix 1. - Meteorological data of Bangalore during the study period (1998 to 1999).

\begin{tabular}{|c|c|c|c|c|c|c|}
\hline \multirow[t]{2}{*}{ Year } & \multirow[t]{2}{*}{ Month } & \multicolumn{2}{|c|}{ Temperature $\left({ }^{\circ} \mathrm{C}\right)$} & \multicolumn{2}{|c|}{$\begin{array}{c}\text { Relative Humidity } \\
(\%)\end{array}$} & \multirow[t]{2}{*}{$\begin{array}{c}\text { Rainfall } \\
(\mathrm{mm})\end{array}$} \\
\hline & & Minimum & Maximum & 7 A.M. (I) & 2 P.M.(II) & \\
\hline \multirow[t]{12}{*}{1998} & January & 16.9 & 28.9 & 92 & 45 & 000.0 \\
\hline & February & 17.5 & 31.1 & 88 & 37 & 000.0 \\
\hline & March & 20.1 & 33.7 & 80 & 31 & 001.0 \\
\hline & April & 22.5 & 35.2 & 81 & 33 & 040.8 \\
\hline & May & 22.6 & 33.9 & 86 & 44 & 041.7 \\
\hline & June & 21.6 & 32.1 & 87 & 53 & 007.4 \\
\hline & July & 20.6 & 28.5 & 90 & 66 & 134.7 \\
\hline & August & 20.4 & 28.2 & 93 & 69 & 319.7 \\
\hline & September & 20.0 & 27.9 & 94 & 68 & 156.1 \\
\hline & October & 19.1 & 28.0 & 94 & 63 & 168.9 \\
\hline & November & 17.7 & 27.1 & 94 & 58 & 040.0 \\
\hline & December & 16.6 & 26.3 & 93 & 52 & 016.9 \\
\hline \multirow[t]{12}{*}{1999} & January & 14.1 & 27.8 & 91 & 36 & 000.0 \\
\hline & February & 15.7 & 29.8 & 91 & 34 & 006.5 \\
\hline & March & 18.1 & 33.4 & 84 & 26 & 000.0 \\
\hline & April & 20.4 & 34.0 & 85 & 37 & 039.4 \\
\hline & May & 20.8 & 30.9 & 90 & 55 & 143.3 \\
\hline & June & 20.0 & 29.7 & 90 & 57 & 043.9 \\
\hline & July & 20.1 & 28.9 & 94 & 64 & 070.6 \\
\hline & August & 19.9 & 28.3 & 91 & 60 & 125.6 \\
\hline & September & 19.6 & 29.0 & 93 & 60 & 128.6 \\
\hline & October & 19.8 & 27.9 & 95 & 66 & 277.5 \\
\hline & November & 16.2 & 26.9 & 94 & 56 & 042.4 \\
\hline & December & 15.5 & 25.6 & 93 & 55 & 019.2 \\
\hline
\end{tabular}

Toon et al. (1991), revealed that seed size has influence on seedling growth (height) at initial stage of nursery and gradually non significant in 12 families of Pinus caribaea. They emphasized that culling at nursery stage should not be based on seed size or speed of germination.

Future studies on $S$. album seed storage, with clonal identity, can help in developing clear cut understanding of viability during storage (clone wise), which may further help in gene pool conservation and strategic supply of seeds for plantation and tree improvement programmes.

\section{Acknowledgements}

Dr. K. S. RAO, Director and Mr. K. S. ReDDY, Group Coordinator, (Research and World Bank FREE Project), IWST, Bangalore have provided facilities and constant encouragement to carry out the present work. The World Bank under ICFRE, Forestry Research Education and Extension Project, Research on Sandal provided financial support.

\section{References}

Allen, G. S. (1960): Factors affecting the viability and germination behaviour of coniferous seed. IV. Stratification period and incubation temperature, Pseudostuga menziesii (Mirb.) Franco. For. Chron. 36: 18-19.

BAGCHI, S. K. and V. P. SHARMA (1989): Biometrical studies on seed characters of Santalum album L. Silvae Genet. 38: 152-153.

BAHADUR, R. and M. S. HoODA (1995): Genetic variability and correlation studies for some pod and seed traits in Khejri (Prosopis cineraria (L.) Druce). Indian Journal of Forestry 18 (2): 161-164.

BHASKAR, V. (1992): Pollination Biology and fertilization in Santalum album L. Santalaceae. Flora (Jena) 187 (1\&2): 73-78.

BRAND, J. E., J. E. D. Fox and M. EfFendi (1993): Variation in seed size and germination of Santalum album L. population in West Timor. Santalum 12: 37-49.

CAMPBell, R. K. and F. C. Sorenson (1984): Genetic implications of nursery practices. In: DURYEA, M. L. and LANDIS, T. D. (Eds.) Forest Nursery Manual: Production of Bare root seedlings The Hague, Martinus nijhoft/ Dr.W.Junk Publ. 183-191.

Chaisurisri, K., D. G. W. Edwards and Y. A. El-Kassaby (1994): Effect of seed size on seedling attributes in Sitka spruce. New Forests 8: 81-87.

Chaisurisri, K., D. G. W. Edwards and Y. A. El-Kassaby (1992): Genetic control of seed size and germination in Sitka spruce. Silvae Genet. 41: 348-355.

Chauvin, J. P. and Y. EHRHART (1998): Germination of two provenances of Santalum austrocaledonicum var austrocaledonicum. In: Sandal and its products. Proceedings of an International seminar, RADOMILJAC, A. M., ANANTHAPADMANABHA, H. S., Welbourn, R. M. and SATYANARAYANA RAO, K. S. (eds), 18-19 Dec. 1997, Bangalore, India, ACIAR proceedings, No. 84, pp 113-116.

CzABATOR, F. J. (1962): Germination Value: An index combining speed and completeness of pine germination. Forest Science 8: 386-396.

EFFENDI, M. and M. SinAGA (1994): Effect of seed size on growth of sandalwood (Santalum album L.) seedlings. Santalum 15: 15-23. 
El-Kassaby, Y. A., D. G. W. Edward and D. W. Taylor (1992): Genetic control of germination parameters in Douglas-fir and its importance for domestication. Silvae Genet. 41(1): 48-54.

Hawkins, C. D. B. (1998): Interactions of Forest seedling Nurseries and Seed Orchards. In: Tree Improvement: Applied Research and Technology Transfer, Sunilpuri (ed.), Oxford and IBH publishing Co. Pvt. Ltd. pp 126-139.

HoodA, M. S. and R. BAHADUR (1993): Variability, correlation and path co-efficient analyses for some seed traits in Subabul (Leucaena leucocephala L.). Seed Research 21(1): 49-51.

IndiRA, E. P., S. Chand BASHA and K. C. CHACKo (2000): Effect of seed size grading on the germination and growth of teak (Tectona grandis) seedlings. Journal of Tropical Forest Science 12(1): 21-27.

International Seed Testing Association (1993): International rules for seed Testing 1993. Seed Sci. Technol. 21 suppliment, Zurich, Switzerland, 288 p.

Johnsen, O., J. Dietrichson and G. Skaret (1989): Phenotypic changes in progenies of northern clones of Picea abies (L.) Karst. grown in a southern seed orchard. III. Climate changes and growth in a progeny trial. Scand. J. For. Res. 4: 343-350.

Jyothi, P. V., J. B. Atluri and C. Subba Reddi (1991): Pollination ecology of Santalum album (Santalaceae). Tropical Eco. 32: 98-104.

Long, E. M. and B. A. Peoples (1991): Nursery management and tree improvement. In: Nursery Management Workshop Proc., Texas, A. and M. Univ. Austin, TX, Texas For. Serv. Publ. No. 148 pp 119-126.

NaGaveni, H. C. and H. S. Ananthapadmanabha (1986): Seed polymorphism and germination in Santalum album L. Van Vigyan 24: 25-28.

PERRY, T. O. and W. L. HAFLEY (1981): Variation in seedling growth rates: their genetic and physiological basis. In: Proc, $16^{\text {th }}$ S. For. Tree improve. Conf., Blacksburg, V.A, May 26-29, 1981 Athens, GA, USDA-USFS, For. Sci. Lab. pp 200-204.

Phanse, V .G. and P. V. Sukhatme (eds.). (1978): Statistical methods of agricultural workers. ICAR Pub. New Delhi, pp. 327.

Reich, P. B., J. Oleksyn and M. G. TJoelker (1994): Seed mass effects on germination and growth of diverse European Scots pine population. Canadian Journal of Forest Research 24: 306-320.

SRImathi, R. A., H. D. Kulkarni and K. R. Venkatesan (1995): Recent advances in Research and Management of Sandal (Santalum album L.) in India. SRIMATHI, R. A., H. D. Kulkarni and Venkatesan, K. R. (eds.) Published by the Associated Publishing Company, New Delhi. P416.

SRInivasan, V. V., V. R. Sivaramakrishnan, C. R. RANGasWAMy, H. S. ANANTHAPADMANABHa and K. H. SHANKARANARAYANA (1992): Sandal (Santalum album L.). Published by the Director, Institute of Wood Science and Technology (ICFRE), Bangalore, pp 233.

Toon, P. G., Haines, R. J. and Dieters, M. J. (1991): Relationship between seed weight, germination time and seedling height growth in Pinus caribaea Morlet var. hondurensis Barret and Golfari. Seed Sci. \& Tech. 19(2): 397-402.

Veerendra, H. C. S. and H. S. A. Padmanabha (1996): The breeding system in sandal (Santalum album L.) Silvae Genet. 45(4): 188-190.

VEerendRA, H. C. S. and C. R. SARMA (1990): Variation studies in sandal (Santalum album L.): 1. Time of emergence and seedling vigour. Ind. Forstr. 119(7): 568-571.

Veerendra, H. C. S., S. Ramalakshmi and B. B. MalleSHA (1999): Variation in seed characterstics in provenances of sandal (Santalum album L.). Ind Forstr. 125(3): 308-312.

\title{
Genetic Variation of Physical and Chemical Wood Properties of Eucalyptus globulus
}

\author{
By L. A. ApiolazA ${ }^{1), 2)}$, C. A. RAYMOND ${ }^{3)}$ and B. J. YeO ${ }^{1)}$
}

(Received $3^{\text {rd }}$ November 2004)

\begin{abstract}
This study considered the degree of genetic variation for diameter $(\mathrm{DBH})$, basic density (BD), predicted pulp yield (PPY), fibre length (FL), microfibril angle (MFA) and cellulose content (CC) amongst eight subraces of Eucalyptus globulus growing in a field trial in NW Tasmania. There were significant subrace effects for BD, FL

1) Forestry Tasmania, GPO Box 207, Hobart Tas 7001, Australia.

2) CRC for Sustainable Production Forestry and School of Plant Science, Private Bag 55, Hobart Tas 7001, Australia.

$\left.{ }^{3}\right)$ State Forests New South Wales, P.O. Box 46 Tumut NSW 2720, Australia. Email: Luis.Apiolaza@forestrytas.com.au, Phone: +61-3-6233 8127.
\end{abstract}

and CC. This variation affected the relative profitability of the subraces for pulp production. On average, the most profitable subraces (on NPV/ha over the base population mean) were Strzelecki Ranges (\$862.04), Western Otways $(\$ 657.80)$ and Strzelecki Foothills (\$576.81). The genetic control (heritability) of variation in DBH, FL and MFA was moderate $\left(0.15<\mathrm{h}^{2}<0.27\right)$, while control for BD, PPY and CC was high $\left(\mathrm{h}^{2}>0.40\right)$. Genetic correlations between growth and wood properties were not statistically significant, except for DBHMFA (-0.86). Most genetic correlations amongst wood properties were outside the parametric space $(<-1$ or $>1$ ), but there were significant correlations between BDMFA (-0.70) and PPY-CC (0.82). The empirical response 